\title{
Effect of Soil Physico-Chemical Properties on Rhizome Rot Disease of Ginger under Assam Condition
}

\author{
K. H. Begum ${ }^{1 *}$, Ashok Bhattacharyya ${ }^{2}$ and R. L. Deka ${ }^{3}$ \\ ${ }^{1}$ (NFSM), District Agriculture Office, Tinsukia-786125, Assam, India \\ ${ }^{2}$ (Agri), Assam Agricultural University, Jorhat-785013, Assam, India \\ ${ }^{3}$ Department of Agrometeorology, Assam Agricultural University, Jorhat-785013, \\ Assam, India
}

*Corresponding author

\section{A B S T R A C T}

\begin{tabular}{|l|}
\hline K e y w o r d s \\
Rhizome rot of ginger, \\
$\begin{array}{l}\text { Soil physico-chemical } \\
\text { properties, Potash }\end{array}$ \\
\hline Article Info \\
\hline $\begin{array}{l}\text { Accepted: } \\
18 \text { May } 2018 \\
\text { Available Online: } \\
\text { 10 June } 2018\end{array}$ \\
\hline
\end{tabular}

\section{Introduction}

Ginger is one of the earliest known oriental spices and is being cultivated in India both as fresh vegetable and as a dried spice, since time immemorial. Ginger is cultivated almost all over the world, covering a total area of 310.5 thousand ha with a production of 1683 thousand metric tonnes (Anon., 2011). India, China, Nepal, Nigeria and Thailand are the top five ginger producing countries, of which India is the largest producer with a production of 702 thousand tonnes accounting $34.6 \%$ of the total world output (Anon., 2014a). In India, ginger is cultivated in almost all the states and the major ginger growing states are
Rhizome rot of ginger is both seed (rhizome) and soil borne disease and plays an important role in the disease incidence and severity. Soil physico chemical properties play an important role in disease severity of rhizome rot of ginger. Correlation studies of six soil physico-chemical parameters with disease incidence (DI) showed that Potash $\left(\mathrm{K}_{2} \mathrm{O}\right)$ content in soil was found exhibit significant negative correlation (-0.78). A ready to use regression equation has been developed to predict the incidence of rhizome rot disease in ginger with $\mathrm{R}^{2}$ value of 61 per cent. 
mycoplasma and nematodes. Among different fungal diseases of ginger, rhizome rot has been considered to be the most destructive disease and is one of the most important production constrains in ginger growing countries (Dohroo, 2005 and Stirling et al., 2009). Rahman et al., (2009) reported that over the years, wilt and rhizome rot disease have affected ginger crop in many NE states resulting a decline of the ratio of seed rhizome to harvested rhizome from 1:8 to 1:4. In Assam, the crop loss was recorded up to 100 per cent in severe cases (Anon., 2007).

Rhizome rot of ginger is both seed (rhizome) and soil borne disease and soil plays an important role in the disease incidence and severity. Soil physic-chemical properties play an important role in disease severity (Sharma et al., 2010 and Kim et al., 2012). Several studies around the world revealed strong correlation of the disease with different soil physico-chemical properties like organic carbon (OC), soil pH, soil texture, electrical conductivity, nitrogen, phosphorus and potassium content of ginger growing soil. Literatures on effect of soil physico-chemical properties on incidence of rhizome rot of ginger is limited except the works of Sharma et al., (2010) and Debnath et al., (2011) and Kim et al., (2012). Sharma et al., (2010) reported a negative correlation of soil $\mathrm{pH}$ and organic carbon with rhizome rot incidence and these two factors may appear as the most effective associative factors influencing the disease incidence. Debnath et al., (2011) reported that disease severity of rhizome rot disease of ginger may dependent primarily on organic carbon content of the soil. Difference in soil $\mathrm{pH}$ of diseased and healthy field was also observed by Kim et al., (2012). Keeping the above points in view, the study was conducted to find the role of soil physicochemical properties on incidence and severity of rhizome rot disease of ginger under Assam condition.

\section{Materials and Methods}

Different rhizome rot infested fields under major ginger growing areas covering all the Agro-climatic zones of Assam were considered in this study. Assam is divided into six Agro-climatic zones. They are: North Bank Plain zone (NBPZ), Upper Brahmaputra valley zone (UBVZ), Central Brahmaputra Valley zone (CBVZ), Lower Brahmaputra Valley zone (LBVZ), Hills Zone (HZ) and Barak Valley zone (BVZ). Eleven (11) soil samples from different rhizome rot infected soil were collected depending on varying disease incidence during 2014. Disease incidence in the rhizome rot infested field was recorded by random samples taken from five different spots of each $2 \mathrm{~m}^{2}$ area. The per cent disease incidence (DI \%) of the specific site was calculated following the procedure given below.

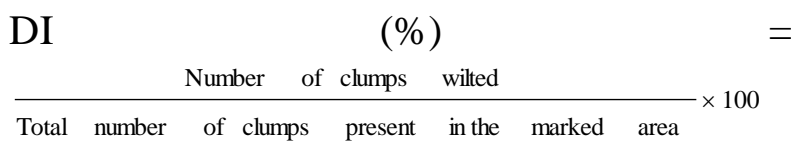

Since ginger plant are not very deep rooted or more confined in surface soils only, soil samples were collected randomly from a depth of $0-30 \mathrm{~cm}$. The soil physico-chemical parameters considered for this study were organic carbon, $\mathrm{pH}$, electrical conductivity, available nitrogen, available phosphorus and available potassium content of the selected sites. along with disease incidence. Electrical Conductivity (EC) and $\mathrm{pH}$ were estimated through Systronics electrical conductivity meter and $\mathrm{pH}$ meter (model number 303 and 335 respectively). For soil fertility analysis, organic carbon was estimated by method given by Walkley and Black (1934). Nitrogen was estimated by Alkaline Potassium Permanganate Method (KMnO4) method given by Subbiah and Asija (1956). Phosphorous estimation was done by the method given Bray and Kurtz, 1945 and 
Potassium was estimated by standard procedure given by Baruah and Bathakur (1997). Correlation as well as regression analyses were performed considering different soil physico-chemical parameters as independent variables and disease incidence (DI) as dependent variables.

\section{Results and Discussion}

It was observed that rhizome rot varied significantly among the six Agro-climatic zones of the state. Highest disease incidence (80\%) was recorded at Tezigaon (UBVZ) whereas lowest $(5 \%)$ being observed at Boko (LBVZ) (Table 1). Variation in the soil organic carbon was observed among the different locations.

Highest organic carbon $(0.79 \%)$ was recorded in Jorhat (UBVZ) and the lowest $(0.48 \%)$ was recorded in Sonari (UBVZ) in the same zone. All the soil samples were found as acidic with soil $\mathrm{pH}$ ranged from 4.90 to 5.88. Very little variations in electrical conductivity (EC) were observed which ranged from 0.02- 0.04.

Analysis of the major soil nutrients from different ginger growing areas showed that available nitrogen and available potash in different locations varied between 271 and $383 \mathrm{~kg} / \mathrm{h}$ and 200 and $342 \mathrm{~g} / \mathrm{kg}$ respectively. Available phosphorus was found to remain more or less same at all the locations. Soil sample with highest Potash (342 g/ $\mathrm{kg}$ of soil) was recorded in Boko (LBVZ) with whereas lowest $(200 \mathrm{~g} / \mathrm{kg}$ of soil) was recorded at Tezigaon (UBVZ).

Ginger is a nutrient exhausting crop. Nagarajan and Pillial (1979) observed the nutritional uptake of the crop. They reported that ginger crops are $\mathrm{N}$ and $\mathrm{K}$ exhausting, intermediary in case of $\mathrm{P}$ and $\mathrm{Mg}$ removal and the least in case of $\mathrm{Ca}$ removal. Correlation as well as regression analyses were performed between disease incidence (DI) and different soil physico-chemical parameters (Table $2 \&$ 3 ) to study the relationship of the soil parameters with disease incidence. Correlation studies showed that except $\mathrm{pH}$, all the other parameters (Table 2) were negatively correlated. It was observed that the correlation between $\mathrm{K}_{2} \mathrm{O}$ content and DI was statistically significant.

Multiple regression analysis was performed with disease incidence and soil physicochemical parameters following step-wise regression method to find the most important parameters contributing to disease incidence. Analysis was done in XLSTAT software where the parameters having significant level at 10 per cent were considered in developing the model.

It appeared that $\mathrm{K}_{2} \mathrm{O}$ content was found to be the single most determinant factor in developing the disease with $\mathrm{R}^{2}$ value of 0.612 . Soil parameters having correlation among themselves were not considered to avoid the effect of multi-collinearity. The regression equation developed to predict the incidence of rhizome rot disease in ginger is as follows.

Disease Incidence (DI in \%) $=105.811-$ $0.2658 * \mathrm{~K}_{2} \mathrm{O}, \mathrm{R}^{2}=0.612$

The regression model between actual and predicted disease incidence is shown in Fig. 1.

Correlation studies of soil physico-chemical parameters with disease incidence (DI) showed that Potash $\left(\mathrm{K}_{2} \mathrm{O}\right)$ content was found to be the most important determinant factor contributing more than $61 \%$ of the disease incidence. Nwaogu and Ukpabi (2010) reported that increasing level of $\mathrm{K}$ fertilization, especially at $\geq 50 \mathrm{~kg} / \mathrm{ha}$, enhanced suppression of pre-harvest yellow leaf spot disease of ginger and the post-harvest rotting of stored fresh ginger rhizomes. 
Table.1 Physico-chemical properties of soil and per cent rhizome rot incidence in ginger

\begin{tabular}{|c|c|c|c|c|c|c|c|}
\hline $\begin{array}{c}\text { Location/ } \\
\text { Agroclimatic } \\
\text { zones }\end{array}$ & OC (\%) & pH & $\begin{array}{c}\text { EC } \\
(\mathrm{mmhos} / \mathrm{cm})\end{array}$ & $\begin{array}{c}\mathbf{N} \\
(\mathrm{Kg} / \mathrm{ha})\end{array}$ & $\begin{array}{l}\mathrm{P}_{2} \mathrm{O}_{5} \\
(\mathrm{ppm})\end{array}$ & $\begin{array}{c}\mathrm{K}_{2} \mathrm{O} \\
\text { (g/kg soil) }\end{array}$ & DI (\%) \\
\hline $\begin{array}{l}\text { Tezigaon } \\
\text { (UBVZ) }\end{array}$ & 0.75 & 5.01 & 0.030 & 370 & 30 & 200 & $\begin{array}{c}80 \\
(63)\end{array}$ \\
\hline $\begin{array}{l}\text { Jorhat } \\
\text { (UBVZ) }\end{array}$ & 0.79 & 5.38 & 0.040 & 370 & 28 & 307 & $\begin{array}{c}10 \\
(18)\end{array}$ \\
\hline $\begin{array}{l}\text { Sonari } \\
\text { (UBVZ) }\end{array}$ & 0.48 & 5.15 & 0.030 & 271 & 24 & 212 & $\begin{array}{l}40 \\
(29)\end{array}$ \\
\hline $\begin{array}{l}\text { BNCA } \\
(\mathrm{CBVZ})\end{array}$ & 0.58 & 5.88 & 0.035 & 310 & 26 & 219 & $\begin{array}{c}70 \\
(57)\end{array}$ \\
\hline $\begin{array}{l}\text { Lakhimpur } \\
\text { (NBPZ) }\end{array}$ & 0.70 & 5.28 & 0.025 & 383 & 27 & 285 & $\begin{array}{c}30 \\
(33)\end{array}$ \\
\hline $\begin{array}{l}\text { Tezpur } \\
(\mathrm{CBVZ})\end{array}$ & 0.52 & 5.82 & 0.020 & 299 & 26 & 214 & $\begin{array}{c}50 \\
(45)\end{array}$ \\
\hline $\begin{array}{l}\text { Boko } \\
(\text { LBVZ) }\end{array}$ & 0.68 & 5.40 & 0.040 & 348 & 31 & 342 & $\begin{array}{c}5 \\
(13)\end{array}$ \\
\hline $\begin{array}{l}\text { Diphu } \\
\text { (HZ) }\end{array}$ & 0.65 & 4.90 & 0.030 & 365 & 29 & 267 & $\begin{array}{c}45 \\
(42)\end{array}$ \\
\hline $\begin{array}{l}\text { Karimganj } \\
(\mathbf{B V Z})\end{array}$ & 0.50 & 5.50 & 0.040 & 295 & 24 & 263 & $\begin{array}{c}50 \\
(45)\end{array}$ \\
\hline $\begin{array}{l}\text { Nagaon } \\
(\mathrm{CBVZ})\end{array}$ & 0.60 & 5.10 & 0.040 & 312 & 26 & 243 & $\begin{array}{c}30 \\
(33)\end{array}$ \\
\hline
\end{tabular}

(Figure in parenthesis is angular transformed value)

Table.2 Correlation matrix

\begin{tabular}{|l|c|c|c|c|c|c|c|}
\hline Variables & OC\% & pH & EC & $\mathbf{N}$ & $\mathbf{P}_{2} \mathrm{O}_{5}$ & $\mathrm{~K}_{2} \mathrm{O}$ & $\begin{array}{c}\text { Disease } \\
\text { Incidence } \\
\%\end{array}$ \\
\hline $\mathbf{O C} \%$ & $\mathbf{1 . 0 0 0 0}$ & -0.4209 & 0.1675 & 0.9256 & 0.7953 & 0.4583 & -0.1808 \\
\hline $\mathbf{p H}$ & & $\mathbf{1 . 0 0 0 0}$ & -0.3322 & -0.3524 & -0.4566 & -0.2238 & 0.2720 \\
\hline $\mathbf{E C}$ & & & $\mathbf{1 . 0 0 0 0}$ & -0.0306 & 0.0224 & 0.4793 & -0.3686 \\
\hline $\mathbf{N}$ & & & $\mathbf{1 . 0 0 0 0}$ & 0.8035 & 0.4773 & -0.0949 \\
\hline $\mathbf{P}_{\mathbf{2}} \mathbf{O}_{5}$ & & & & & $\mathbf{1 . 0 0 0 0}$ & 0.4842 & -0.1728 \\
\hline $\mathrm{K}_{\mathbf{2}} \mathbf{O}$ & & & & & & $\mathbf{1 . 0 0 0 0}$ & $\mathbf{- 0 . 7 8 2 1}$ \\
\hline $\mathbf{D I} \%$ & & & & & & & $\mathbf{1 . 0 0 0 0}$ \\
\hline
\end{tabular}

* Values in bold are different from 0 with a significance level alpha $=0.05$ 
Fig.1 Predictive model between actual and predicted disease incidence

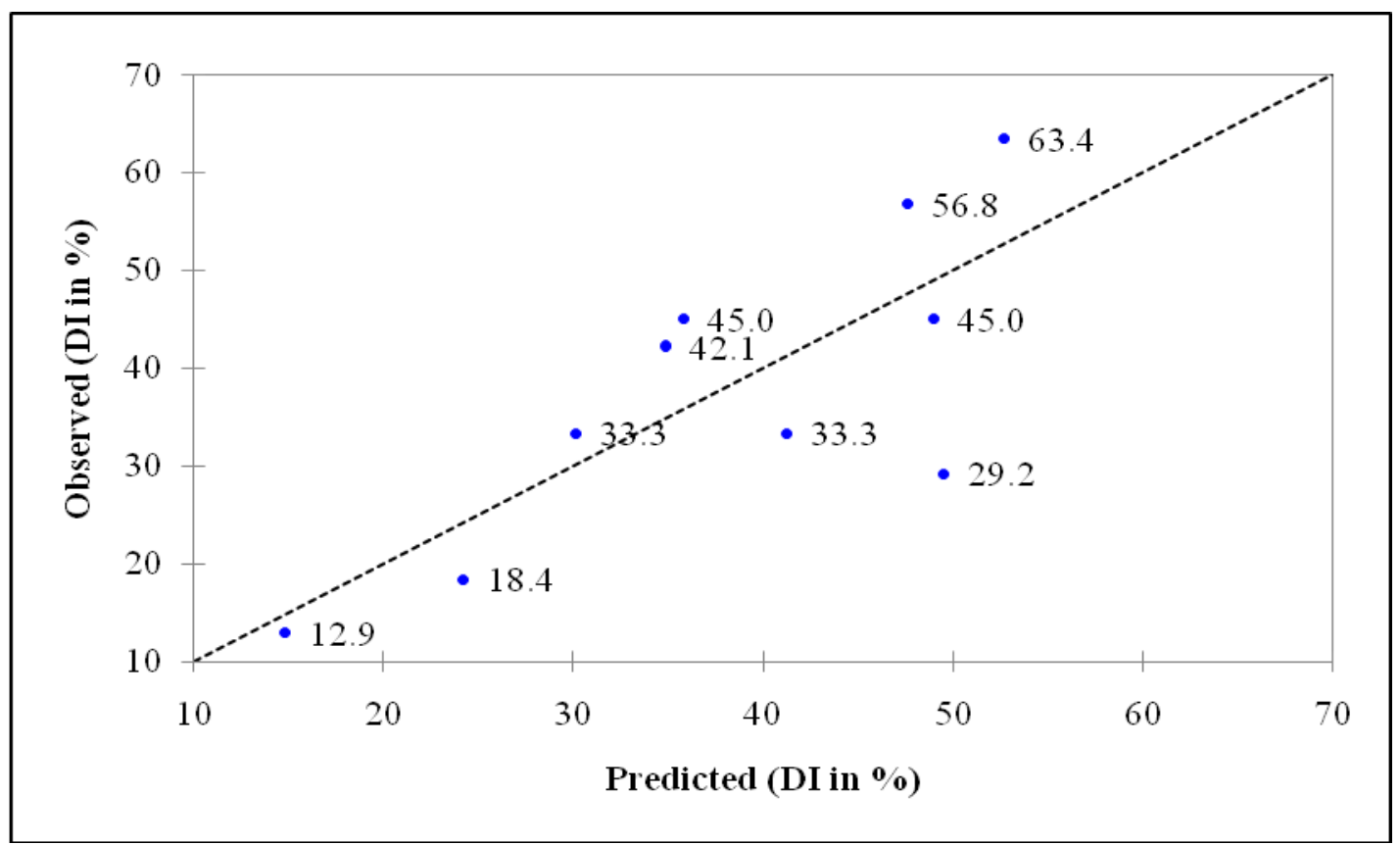

Li et al., (2010) reported that ginger is sensitive to potash and needs a large amount of available soil Potassium. The demand of Potassium fertilizer was found to be at peak during active growth period of the crop. They also reported that Potassium is the important limiting factor for ginger production in China. Similar observations were also reported by Srinivasan et al., (2012) from India. They reported that Potash is one of the most important limiting factor for poor production of ginger in India as the crop removes a large amount of soil Potash (up to $500 \mathrm{~kg} / \mathrm{ha}$ ). This study also indicated the important role of $\mathrm{K}_{2} \mathrm{O}$.

Rhizome rot of ginger is both seed (rhizome) and soil borne disease and soil plays an important role in the disease incidence and severity. Correlation studies between six different physico-chemical parameters of soil with disease incidence (DI) from eleven rhizome rot infected sites showed that Potash $\left(\mathrm{K}_{2} \mathrm{O}\right)$ content was found to be the determinant factor contributing more than $61 \%$ of the disease incidence.

\section{References}

Anonymous (2014a). Source: Food and Agricultural Organization of the United Nations, FAOSTAT.

Anonymous, 2007. Annual Report 2006-07, Technology mission for North east India and Himalayan states (MM1), Assam Agricultural University, Jorhat, Assam

Anonymous, 2014 b. Source: Indian Horticulture Database-2014, National Horticulture Board, Ministry of Agriculture, Govt of India

Baruah, T.C. and Barthakur, H.P. 1997. Determination of available potassium in soil. In: (A Textbook of Soil Analysis). Vikas Publishing House, Pvt. Ltd., pp. 89- 93.

Bray, R.H. and Kurtz, L.T. 1945. Determination of total organic and available form of phosphorous in soil. Soil Sci. 59: 39-45.

Debnath, A.; Bandyopadhyay, S and Dutta, S. 2011. Correlation studies including physico-chemical properties of ginger- 
soils from different location of Cooch Behar and rhizome rot and wilt disease severity in ginger. J.Mycopathol.Res.49:367-368

Hazarika, D.J. and Kakoti, M. 2013. Study on the Indigenous Varieties of Ginger of Golaghat district Assam and its Economic Viability as Aroma Ingredients. J. Nat. Prod. Plant Resour. 3: 24-29.

Kent, A.D. and Triplett, E.W. 2002. Microbial communities and their interactions in soil and rhizosphere ecosystems. Annu. Rev. Microbiol. 56:211-236

Kim, G.D.; Lee, E.M. and Ahn, T.Y. 2012. Physico-Chemical Properties and microbial populations and diversity in soils where rhizome rot disease of Ginger frequently occurs. Proc. XXVIIIth IHC - IS on Envtl., Edaphic and Gen. factors affecting plants, Seeds and Turfgrass. Acta Hort. 938

Li, L.; Chen, F.; Yao, J.W.; Ding, N. and Liu, X. 2010. Balanced Fertilization for Ginger Production- Why Potassium Is Important. Bett. Crops Pl. Fd. 94: 2527.

Nagarajan, M and Pillai, N.G. 1979. A note on the nutrient removal by ginger and turmeric rhizomes. Madras Agric.J. 66:56-59

Nwaogu, E.N. and Ukpabi 2010. Potassium fertilization effects on the field formances and post-harvest characteristics of imported Indian ginger cultivars in Abia State, Nigeria. Agril. J. 5: 31-36.

Rahman, H.; Karuppaiyan, R.; Kishore, K. and Denzongpa, R. 2009. Traditional practices of ginger cultivation in Northeast India. Indian J. Trad. Knowl. 8: $22-28$

Sharma, B.R.; Dutta, S.; Roy, S.; Debnath, A. and Deroy, M. 2010. The effect of soil physico chemical properties on rhizome rot and wilt disease complex incidence of ginger under hill climatic region of West Bengal. Plant Pathol. J. 26: 198202.

Srinivasan, V.; Dinesh, R. and Hamza, S. 2012. Management of acid soil for sustainable production of spices in India. $8^{\text {th }}$ International Symposium on Plant Soil Interactions at Low $\mathrm{pH}$. Held from October 18 to 22, 2012 in University of Agricultural Sciences, Bengaluru".

Subbiah, B and Asija, G.L. 1956. A rapid procedure for estimation of available nitrogen in soils. Curr. Sci. 25(8).

Walkley, A. and Black, T. A. 1934. Estimation of soil organic carbon by chromic acid titration method. Soil Sci. 37: $29-38$.

\section{How to cite this article:}

Begum K. H., Ashok Bhattacharyya and Deka R. L. 2018. Effect of Soil Physico-Chemical Properties on Rhizome Rot Disease of Ginger under Assam Condition. Int.J.Curr.Microbiol.App.Sci. 7(06): 2097-2102. doi: https://doi.org/10.20546/ijcmas.2018.706.248 